УДК 371.3

\title{
ВИХОВНА ІНЖЕНЕРІЯ ПО-ЯПОНСЬКИ
}

\author{
Голос Г. А. \\ golos.anna@gmail.com \\ Київський наиіональний лінгвістичний університет \\ Дата надходження 23.10.2018. Рекомендовано до друку 26.11.2018.
}

\begin{abstract}
Анотація. У статті зроблено спробу висвітлити історію розвитку системи освіти та виховання в Японії на тлі суспільно-політичних та культурних трансформацій у період Мейдзі $(1868$ - 1912). Окрему увагу приділено виховній практиці і змісту виховання в сучасній японській школі.
\end{abstract}

Ключові слова: виховання, моральне виховання, зміст морального виховання, історія педагогіки.

Голос Г. А. Киевский национальный лингвистический университет

Воспитательная инженерия по-японски

Аннотация. В статье предпринята попытка раскрыть историю развития системы образования и воспитания в Японии на фоне общественно-политических и культурных трансформаций в период Мейдзи (1868 - 1912). Особое внимание в статье уделяется воспитательной практике, ее содержанию в современной японской школе.

Ключевые слова: воспитание, моральное воспитание, содержание морального воспитания, история педагогики.

Holos H. A. Kiev National Linguistic University

Value education engineering in Japanese

Abstract. Introduction. With the regard to new education reform undergoing in Ukraine ("Nova Ukrainska shkola" (New Ukrainian school), one should not neglect cross-cultural advances. Education systems, despite cultural diversity, are unique in having common aims. The case of Japan, worldwide known for meritocratic nature of its society, provides an opportunity to look at effective schooling, as well as at successful collaboration of "parents - school - caring community" triad. Purpose of this paper is to outline the genesis of education system in Japan. Namely, the period from 1868 to 1912 (referred to the Meiji era) and till the present day. The special attention is paid to contemporary system of value education, its contents in Japanese schools. Methods used to conduct the research are: publications study and analysis. Results. The retrospective analysis shows that the Meiji period $(1868$ - 1912) is a time segment in Japan that contributed significantly to the economic leap leading to the prosperity of the country. The period was quite complicated, balancing between liberal and conservative stances that, nevertheless, launched modernization processes in the whole spheres of society, including education. Having modeled its educational of system on the western pattern, Japan managed to preserve its national style in moral education, remaining relatively unchanged for many decades. Currently there are three pillars of contemporary value education: moral classes, special activities (tokkatsu), explicit curriculum (value education is incorporated either in academic, or non-academic subjects). Special activities is a distinctive element that can be, obviously, learnt from Japanese schooling. It comprises classroom and club activities, student council and volunteering, school events and fieldwork, enabling schoolchildren fully experience/participate in prosocial activities. Conclusions. By pointing out all the benefits of Japanese schooling, it is obvious that the Japanese educational system has its weak points and challenges (demographic issue; the attitude to immigrant children; a gender problem in the employment youth market; increasing number of children ets.). Examining both advantages and disadvantages of Japanese educational system provides insight on contemporary schooling in Japan, and will help to understand strength and weakness of value education in Ukraine better.

Keywords: value education, moral education, contents of moral education, history of pedagogy.

Постановка проблеми. Теоретизація шкільного виховання в Україні як педагогічна проблема розглядається відносно недавно. Це пов'язано, передусім, із низкою загальновідомих усім соціально-історичних причин, що склалися в Україні на початку 20-х років ХХ ст., i що, власне, обумовило відстрочення наукового інтересу українських освітян-науковців до питання національного змістотворення до початку $90-$ х років. 
У світлі нової освітньої реформи сучасна українська педагогіка вже має офіційно окреслений виховний орієнтир (“Український виховний ідеал”, “Національна програма виховання дітей та юнацької молоді в Україні” (2004) та відповідний план його (“Нова українська школа” (2016) реалізації, свідками якого є сьогоднішні українські педагоги, школярі та їхні батьки.

Наразі українські школярі не тільки радо співають гуртом національний гімн у школі, з гордістю вдягають національну вишиванку, охоче беруть учать у національно-патріотичних виховних заходах, а й долучаються до проактивної діяльності: самоврядування, благодійних акцій, місцевих заходів. Такі нововведення, безумовно, свідчать про позитивні зміни у національній виховній системі.

3 іншого боку, на практиці існують чинники, що вносять дисонанс у виховну практику шкіл. Такими об'єктивними чинниками є: другорядне ставлення українського загалу до дисциплін, в яких інтегровано виховання; штучний виховний клімат шкіл; низький рівень залучення місцевої громади; терпимість до такої соціальної патології, як булінг, соціальні нерівності; обмаль релевантних дискусій для юнацтва (самооцінка, вирішення конфліктів, свідомий профвибір, робота з емоціями та ін.) і безкоштовних шкільних гуртків різного профілю (спортивного, технічного, прикладного).

Зважаючи на те, що вищезгадані чинники згідно з новою реформою $\epsilon$ вкрай суттєвими у питанні побудови небайдужої до дитини (зарубіжні теоретики використовують термін caring: caring schools, caring communities) нової української школи, повчальним видається зарубіжний досвід організації виховання, де 1) віддавна реалізується педагогіка дитиноцентризму; 2) консолідуються зусилля усіх соціальних інститутів, створюючи адекватні умови і можливості для розвитку і реалізації дітей і юнацтва; 3) де природа, історія, музика, література і спорт повною мірою реалізують свою виховну, культуротворчу функцію; піднесені до рівня важливих предметів. Науковий інтерес становить не неповна модель, а активний, цілісний процес соціалізації і культурації дітей та юнацтва. Японський досвід у цьому контексті - один із “демонстративно успішних" (“Јapanese education”), зокрема, як засвідчують наукові розвідки, i для економічно розвинутих країн. Інтерес підсилюється також надзвичайним впливом, який справляють японські жанри поп- культури на сучасних дітей і юнацтво безвідносно їх громадянства (бойові мистецтва, ментальна математика, бейблейд, покемони, аніме, манга, косплей, комп'ютерні ігри тощо).

Аналіз останніх досліджень і публікацій. Цінну інформацію про культурні особливості, виховання, шкільництво в Японії було представлено в історичних, етнографічних публікаціях, монографіях, соціологічних, компаративних дослідженнях минулого і теперішнього - це роботи R. Benedict, Y. Khan, R. Fukuzawa, R. Tsuneyoshi, T. Lebra, C. Lewis, G. Letendre, P. Cave, T. Rohlen, K. Anderson-Levit, L. Peak, M. White, Å. Vogel, A. Imamura, W. Cummings, T. Naito, Б. Пільняка, М. Конрада, О. Мещерякова, Е. Молодякової, В. Молодякова, В. Маркар'яна, І. Кона, Л. Гришельової, Н. Чегодарь, В. Рубеля,Т. Свердлової,Т. Кучай, Н. Пазюри та ін.

Мета статті - подати погляд на японську систему виховання в об'єктиві XXI століття 3 акцентом на історичному відрізку докорінного переустрою країни, що отримав назву “реставрація Мейдзі" (1868 - 1912) - період балансування між ліберальними і консервативними віяннями, що дав Японії змогу не тільки вийти зі світової периферії, а й стати помітною фігурою на сучасній міжнародній арені.

Основні результати дослідження. Розпочнімо огляд з перебігу і наслідків модернізаційних змін в японському соціумі та їх місця в освітній політиці.

Процес становлення японської культури нового часу припадає на другу половину XIX ст. період Мейдзі (буквально означас “просвітницьке правління"), коли під тиском зовнішніх сил Японія вимушено припиняє понад двохсотрічну самоізоляцію. Усвідомлюючи усі науковотехнологічні переваги Заходу, як “стимулююче добриво” (Reischauer, 1995, p. 409) Японія 
обирає євро-американський взірець. До того, як відомо, культурними донорами Японії були Корея і Китай. Запозичена у сусідів архітектурна стилістика, система державного устрою та імператорської влади, писемна культура і релігія впродовж століть входила в японську культуру, піддаючись локальному впливу. Подібний шлях гібридизації, як довела історія, чекав на Японію попереду.

У перші роки надолуження Заходу процес модернізації відбувався методом спроб і помилок, багато в чому на шкоду японським національним інтересам. Незважаючи на космополітичний характер, запозичення прозахідних культурних штампів проходило наосліп, екстенсивно, подеколи приймаючи комічний вигляд (тут ідеться про символ вестернізації - "Палац оленячого крику” (палац прийомів Рокумейкан), що дав підставу консервативній частині японців назвати новий уряд “танцюючим”). Бажання репрезентувати себе цивілізовано в очах прогресивного Заходу позначалось не тільки на забороні кастово-класової системи, реформі календаря, загальновійськовій повинності, скасуванні монополії самурайства у військовій сфері, а й забороні звичного для японців способу життя (татуювання, відвідування публічних бань, продаж порнографічних гравюр і навіть традиційна японська чоловіча зачіска - довге волосся, зібране у пучок на маківці) (Гришелева, Чегодарь, 1998, с. 25).

Усвідомлюючи реальну роль населення у розвитку економіки країни, яка $є$ “бідною на корисні копалини і яка систематично бореться з природними катаклізмами” (Молодякова, 1996, с. 66), японський уряд ідеологічно вдало трансформує національну ідею. Все, що колись складало масову культуру, було використано як символічна репрезентація Японії та іiі висококультурний спадок на перших міжнародних виставках (у Парижі (1867) і Відні (1873). Майстерно вироблений, екзотичний для європейців крам викликав неабиякий інтерес, спричинивши у Європі справжній бум, що “з подачі французької критики” отримало назву japonisme (Молодякова, 2014, cc. 159, 162). За тоді ще економічно нерозвинутою Японією закріплюється назва "країна ремесел".

У наступне десятиліття прозахідний ажіотаж дещо спадає. Суспільне обурення, викликане необміркованим запозиченням прозахідних цінностей і нехтуванням власних національних, переважує супроти першого. Суспільна ностальгія за “золотою епохою ізоляції”, невдоволення консервативно налаштованої частини суспільства обраним курсом на "цивілізацію і просвітництво" змушує уряд вести політику більш виважено, враховуючи доцільність зарубіжного досвіду для своєї країни. Так, відкидаючи більшість систем за надмірну демократичність, найбільш вдалим зразком державного порядку для себе Японія обирає олігархічну Пруссію, їі досягнення у реформуванні медичної галузі; а приклад будівництва залізниці, доріг i, власне, лівосторонній рух було запозичено в англійців; уявлення щодо ведення бізнесу, естетичні віяння, кіноіндустрія - у Сполучених Штатів Америки (Емота, 2018, c. 26).

Крок за кроком відбуваються системні зміни і в освіті: основу нової системи освіти у 1872 склала гібридизована франко-американська модель (адміністративний контроль першої, початкова, середня школи та університет - другої).

Традиційні заклади освіти було трансформовано: теракої - у початкові школи, ханко (колишні школи для самураїв) - у середні та інкорпоровано у нову систему (“Education in Japan"). У початковій школі викладалась каліграфія, арифметика, мораль, японська мова, історія Японії, географія, малювання, співи, етикет, традиційні бойові мистецтва (хлопцям), рукоділля (для дівчат). У середній школі - учні продовжували вивчати мораль, японську мову, китайську класичну літературу (“Класика синівського пієтету”, “Велике повчання”) (Zhao et el., 2010 , р. 185), іноземну мову (англійська, німецька, французька), історію, географію, математику, природничі науки, право, економіку, малювання, музичне мистецтво, традиційне бойове мистецтво. Що цікаво, китайська домінанта з іï “аурою великого минулого” (Reischauer, 1995, 
p. 404) співіснувала в тогочасній японській системі виховання аж до японо-китайської війни (до слова, до війни Японія була фактично білінгвістичною країною (Молодякова, 2014, с. 114), адже підручники були написані японськими авторами.

Оскільки кваліфікованих педагогів не вистачало, заміну до початку 80-х років склали вчителі старої школи - самураї, для яких викладання як державна служба у світлі наставництва дітей та юнацтва було не менш гідною справою, ніж військова. Великий відсоток серед учнів також становили вихідці із самурайських сімей, що багато в чому вплинуло на моральний клімат країни у післявоєнний період (Гришелева и Чегодарь, 1998, с. 46).

На запрошення уряду до викладання фізико-математичних дисциплін до Токійського університету приїздять іноземні фахівці, які презентують лекції сотням японських педагогів. Власне від чого закріпилась традиція показових уроків - невід'ємної частини сучасної системи професійної підготовки вчителів в Японії (Isoda, Stephens, Ohara, Miyakawa, 2007; Lewis).

1899 рік стає прикметним у зв'язку із виходом положення про відкриття фахових шкіл, згідно з яким випускники середньої школи могли обирати собі спеціалізацію: педагогічний, технічний, комерційний чи аграрний ухил. У 1903 р. відкриваються професійні коледжі (senmon gakko) із правом вступу до них учнів середньої і старшої жіночої шкіл (факультети медицини, юридичний, фармакології, інженерний, комерції). Створена по всій країні мережа різнопрофільних шкіл, коледжів, наукових центрів багато в чому допомогла налагодити серійне виробництво товарів на експорт.

Попри офіційний імператив, освітня реформа не одразу зустріла схвальне ставлення японців, що зумовлювалось не тільки уведенням платні за освіту, непосильної для бідного селянства (до 1900), відсутністю належного фінансування шкільної реформи (основна частина коштів покривала навчання фахівців за кордоном і високу заробітну плату зарубіжних лекторів, утримання Токійського державного університету), а й відривом сільських дітей від сезонних робіт (Zhao et el., 2010, p. 188). Результатом незадоволення нерідко ставали пошкоджена шкільна будівля, зрив шкільних зборів, погане відвідування. Так, у перші роки Мейдзі більшість школярів відвідували школу не більше ніж рік-півтора. I навіть до 1902 до кінця четвертого класу початкової школи доходило 65\% загальної кількості учнів (Гришелева и Чегодарь, 1998, с. 41; Zhao et el., 2010, p. 188). Незважаючи на повільну динаміку освітньої реформи, як зазначає К. Окано, “як тільки освіта пустила корені на японській периферії, виникло розуміння її сутті” (Zhao et el., 2010, p. 183). Якщо на початку реформ ключовою була прозахідна орієнтація, то зі зміною політичного клімату від кінця 80-х - під впливом зміцнення ідей крайнього монархізму і національної винятковості - освітній курс отримує націоналістичне спрямування. Чітко це простежується на прикладі системи виховання того періоду.

Як доводять джерела, до 1880-х років моральне виховання в Японії викладалось тільки у початковій школі (shushin дослівно “самодисципліна”), спираючись на конфуціанство та західний ідеал вільної людини (Roesgaard, 1995, p. 177). Школярі вивчали життя визначних діячів (Конфуція, Шотоку Тайши, Бенджамін Франкліна, Сократа, Джорджа Вашингтона, Ніномія Сонтоку і Флоренс Найтінгейл та ін.), читали оповідки в перекладі із західної літератури (“The British Moral Class Book", "Elements of Moral Science”, байки Езопа); поширеним підходом у навчанні моралі були переповідки казок (зазвичай, регіональних, характерних для того чи іншого регіону країни) (Maruyama, 2013).

Від 1890-х р. західний виховний ідеал було остаточно відкинуто, на що вплинула поява і закріплення у соціумі ідеї винятковості японської нації. Як зазначає Токутомо Сохо, концепція “чужої нації” породила концепцію “японської націӥ” (Cacizares-Esguerra, Maryks, Po-Chia Hsia, 2018, p.18). Невдовзі у світ виходить Імператорський рескрипт, на державному рівні дістає поширення синтоїзм і концепція бусідо - чинники, що безпосередньо вплинули на шкільництво і зміст виховання. 
Імператорський рескрипт (1890) фактично став завершальним довоєнним періодом становлення національної освіти в Японії. Рескрипт проголошував стандарти поведінки японців, підкреслюючи цінність патріотизму та відданості Імператору. Навколо цього документа будувався і зміст виховання (нижче подаємо частину рескрипту, який учні і вчителі декламували щоденно перед портретом імператора):

....Бути сином своїм батькам, люблячим до братів і сестер; як чоловік і дружина бути у гармонії, як друзі вірні; поводити себе скромно; удосконалюватись; розширювати свою доброзичливість до всіх, вивчати і культивувати мистецтво, тим самим розвиваючи інтелектуальні здібності та досконалі моральні сили; плекати суспільне благо та сприяти спільним інтересам; завжди поважати Конституцію і дотримуватися законів; у разі небезпеки відстоювати мужньо державу; і таким чином охороняти і підтримувати процвітання нашого Імперського Трона, однолітка небес і землі .... (Passin, 1965, p. 151).

В умовах нагнітання військової агресії психологічний тиск рескрипту на свідомість молодого покоління (та і усього населення) був настільки сильний, що “інфікував” японців фанатичною жертовністю у подальший воєнний період.

Окрім рескрипту, другий суттєвий чинник, що вплинув на розвиток японської системи виховання вже у післямейдзійську добу, - ідеологічне використання релігії на користь національного згуртування. Оскільки Конституція 1889 р. забороняла втручання релігії у державні справи, рескрипт узаконив синтоїзм на державному рівні (de jure не вважався релігією), проповідуючи культ предків і божественне походження імператора. На знак пошани національних символів учні мали обов' язково дотримуватися обрядів/ритуалів синто (Benedict, 1946, p. 303). У поєднанні із конфуціанськими засадами синтоїзм було інтегровано у курс моралі, історію Японії, шкільну діяльність. У 1892 р мораль як предмет отримує безпрецедентну перевагу над рештою дисциплін; викладається згідно із затвердженими урядом директивами. Додатково до рескрипту для шкільного курсу моралі був розроблений розгорнутий коментар (Гришелева и Чегодарь, 1998, с. 145). Він містив теми синівського боргу, щирості, скромності, правил поведінки, шанобливого ставлення до імператора і любові до Батьківщини, що також були інтегровані в предмети краєзнавчого плану.

Незважаючи на те, що політика провадилась у дусі націоналізму, 1930 року побачив світ трактат Цунесабуро Макігучі “Педагогічна система Сока” (буквально “творення цінностей”). Гуманіст виступив проти військової політики уряду, закликаючи вчителів зберегти цінності справжньої педагогіки (Ікеда, 2013, с. 156). Сьогодні послідовником гуманістичної педагогіки Макігучі в Японії є Дайсаку Ікеда.

У цей самий період поширення дістає викривлена концепція бусідо (найпопулярніша, напевно, з книг - книга I. Нітобе “Бусідо. Душа Японії; книги Н. Кайтена, Д. Юдзана, Я. Цунетомо) - третій чинник, що позначився на виховному кліматі в школі. Як зазначає Дж. Херст, помилково думати про існування єдиної школи під назвою “Бусідо”, адже протягом середньовіччя в Японії існувало чимало кодексів військових домів, фамільних заповітів та інших документів, що підтримували етичні цінності серед самураїв. Тільки у період 1600-1868 pp. (період Токугави) самураї стають грамотними, з'являються роботи, написані ними. Частина 3 них - праці з моральної філософії, написані мовою, практично недоступною сучасній молоді складною для розуміння і читання. Інша частина робіт - правила поведінки воїнів, написані 3 неоконфуціанської точки зору. Тому у передвоєнний і воєнний періоди, на думку Д. Херста (c. 23), було б правильніше говорити про бусідо як про моральний вишкіл солдат імператорської армії, а також військову ідеологію, спроектовану на весь масив японського суспільства.

У післявоєнний період Імператорський рескрипт (замінено “Фундаментальним Законом про освіту” (1947), як і моральне виховання з його девіантною ідеологією, було заборонено. Лінія спадкоємності військової ідеології була перервана включно до наших днів, коли про бусідо знову заговорили у світлі політики прем'єра міністра Японії Сіндзо Абе, який прагне зміцнити оборонну міць Японії, переглянувши 9-й “пацифіський” пункт конституції. Власне, 
трагічні події XX ст. (мається на увазі вбивство корейської імператриці Мін, окупаційний націоналізм, жінки-комфорту, “нанкінська різанина”, проблема пов'язана із храмом Ясукуні) $\epsilon$ досі болісним спогадом в історичній пам'яті японців, про який не прийнято говорити або про який згадують, як про спадок, не пов'язаний із сучасністю (Молодякова, 2014, с. 63, 64). Незважаючи на те, що самурайська доба висвітлюється у шкільних підручниках, як правило, у дусі самурайського романтизму, сучасні випускники шкіл навряд чи знають достеменно про корені Бусідо, як і про те, що його прихильники були ревними послідовниками Дзенбуддизму (Молодякова, 2014, с. 63). У 1950-х роках відроджуються традиційні бойові мистецтва (було легалізовано), що стають не тільки частиною клубної діяльності в японських школах, а й потужним інструментом японської культурної політики глобально (Молодякова, 2014, с. 131).

Нову модель освіти склали: система 6-3-3-4 (обов'язкова освіта - 9 років, включаючи початкову (6 років) та молодшу середню школу (3 роки); випускники молодшої середньої школи мають вибір продовжувати навчання у старшій середній школі (3 роки) або здобувати фах у політехнічних закладах освіти; 4 роки - університет); змішані класи; педагогічні ради на префектурному і муніципальному рівні. Систему виховання було переорієнтовано на практичні, демократичні цінності, відкритість, поза будь-якої форми індокринації. Географію та історію було тимчасово вилучено зі шкільної навчальної програми до появи їх у складі соціальних дисциплін. На час перезавантаження моральне виховання було замінено на громадянське виховання (komin), що викладалось у школі кілька років за західним підходом, а у 1958 році як курс морального виховання (dotoku no jikan) (буквально "шлях чеснот"), що враховував специфіку японського суспільства.

У 1965 році Центральна Рада з освіти представила японський виховний ідеал, що охоплював чотири змістові частини: 1) обізнаність про себе (помірність, старанність, свобода і порядок, щирість, творчість, Я-образ), 2) стосунки з іншими людьми (ввічливість, опіка, довіра, дружба, скромність, відкритість, задоволення від співпраці), 3) відносини між групами та суспільством (співпраця, законослухняність, відповідальність, чесність, внесок у суспільство, повага старших, повага вчителя, повага традицій і любов до свого народу) і 4) стосунки з природою/всесвітом (повага до природи, життя, естетична чутливість, благоговіння перед силою природи над людиною) (Naito, 1990). Цей стандарт активний у поточних офіційних документах (втім, сама назва “Японський ідеал” в офіційних документах рідко вживається на противагу змістовим частинам); враховується при плануванні уроків морального виховання (зокрема, у підручниках з морального виховання, Kokoro no noto (“Шоденник серця”). 31968 році в японських школах почали впроваджувати спеціальну діяльність (tokubetsu katsudo). Спочатку для учнів початкової і молодшої середньої школи, а згодом у 1977 р. - i для учнів старшої середньої школи ("The World of Tokkatsu").

Кожні десять років в Японії прийнято вносити корективи в освітню політику відповідно до вимог часу, без зміни базових документів (“Фундаментальний закон про освіту”). Так, завдання розвитку автономності дітей, здатності самостійно мислити і знаходити рішення, бути креативним були викликами 80-х років (Cave, 2016, p. 77). У 1998 р. було введено курс інтегрованого навчання (“The World of Tokkatsu”); освітні дебати були зумовлені інтерналізацією, пов'язаною із необхідністю залучати на ринок праці іноземців. У 2000-х роках зміни торкнулись розвантаження шкільного розкладу (шестиденний тиждень у 2002 році було скорочено до п'яти днів); наголошувалось на прищепленні “родзинки/жаги до життя" (лозунг сучасної реформи) - корективи пов'язані із необхідністю послаблення інтелектуального перенапруження школярів, зростанням випадків суїцидів і булінгу. Головними цілями сучасної школи визначено: всебічний розвиток, передачу знань, культурацію і соціалізацію, профселекцію і профдиференціацію (Okano, Oprandy, Tsuchiya, 1999, p. 4).

Отже, вітчизняні і зарубіжні японознавці справедливо вважають, що коріння успішності Японії слід шукати у національному характері японців, серед переліку рис якого: висока 
адаптивність нації до нового, національна згуртованість, вражаючі мобілізаційні здібності. Без жодної аналогії у західних країнах, за XX ст. Японії вдалось не тільки двічі подолати економічну відсталість (у до- і післявоєнний періоди), а й модернізувати свою країну до високого рівня та якості життя, зберігаючи при цьому свій культурний націоналізм. Велика роль у зростанні суспільного ресурсу в Японії, безумовно, належить освіті, фундамент якої було закладено у період Медзі (1868 - 1912). Виховання у довоєнний період мало радикально націоналістичне спрямування; зміст грунтувався довкола світоглядних й політичних настанов тогочасного уряду. Післявоєнний період відкрив нову сторінку в історії Японії, заклавши основи становлення демократичного суспільства. В Основному Законі про освіту (№ 120 від 2006 р.) йдеться про необхідність культивувати у дітей та юнацтва моральність й етику, показувати їх значущість у шкільному житті (Maruyama, 2013). Зупинимось же на особливостях сучасної системи виховання в Японії докладніше.

Як зазначала в своїй класичній роботі Р. Бенедикт (Benedsct 1946, с. 1946, с. 807). Траєкторія життя в Японії подібна до неглибокої U-подібної кривої (Benedsct, 1946): максимальною свободою і поблажливістю тут користуються немовлята і люди похилого віку. Із входженням у зріле життя ця крива очікувань поступово зростає, що аналогічно простежується і в японському шкільництві. Початкова школа - перехідний етап від відносної свободи раннього дитинства до інтеріоризації шкільних правил і норм; відрізок, на якому підкреслюються цінності дружби і співпраці, розвиток самостійності і становлення характеру. Середня школа (7 - 12 класи) є стежкою у доросле життя; час, коли юнацтво вже розуміє спектр вимог, важливих для суспільства і своєї громади. Для 5\% випускників молодшої середньої школи це період свідомого самовизначення щодо фаху, тоді як для більшості (94\%) - час апріорі серйозної доуніверситетської підготовки.

Сучасну систему виховання можна порівняти із виховною інженерією, що планує, конструює, активно облаштовує кожен окремий шкільний відрізок життя людини. Система охоплює урізноманітнені форми роботи. ІЇ̈ трьома "китами" є: 1) уся діяльність в школі, в яку інтегроване виховання; 2) курс морального виховання; 3) спеціальні види діяльності (tokubetsu katsudo, або коротко tokkatsu) як обов'язковий елемент. Щоб чіткіше побачити складники виховання у навчальній програмі, нижче подано таблицю із зазначеною кількістю годин, відведених на моральне виховання і спеціальну діяльність в елементарній і молодшій середній школі.

Початкова школа

\begin{tabular}{|c|c|c|c|c|c|c|}
\hline \multirow{2}{*}{ Предмет/години } & \multicolumn{6}{|c|}{ Класи } \\
\hline & 1 & 2 & 3 & 4 & 5 & 6 \\
\hline Читання & 306 & 315 & 245 & 245 & 175 & 175 \\
\hline Соціальні науки & & & 70 & 90 & 100 & 105 \\
\hline Математика & 136 & 175 & 175 & 175 & 175 & 175 \\
\hline Фізика/хімія (Науки) & & & 90 & 105 & 105 & 105 \\
\hline Life science (Охорона життя) & 102 & 105 & & & & \\
\hline Музика & 68 & 70 & 60 & 60 & 50 & 50 \\
\hline Мистецтво & 68 & 70 & 60 & 60 & 50 & 50 \\
\hline Домашня економіка & & & & & 60 & 55 \\
\hline Фізична культура & 102 & 105 & 105 & 105 & 90 & 90 \\
\hline Моральне виховання (курс ) & 34 & 35 & 35 & 35 & 35 & 35 \\
\hline $\begin{array}{l}\text { Іноземна мова } \\
\text { (види діяльності мовленнсвої) }\end{array}$ & & & & & 35 & 35 \\
\hline Інтегроване навчання & & & 70 & 70 & 70 & 70 \\
\hline Спеціальна діяльність & 34 & 35 & 35 & 35 & 35 & 35 \\
\hline Загальна кількість & 850 & 910 & 945 & 980 & 980 & 980 \\
\hline
\end{tabular}

Цит. за: http://mext.go.jp/a_menu/shoyou/new-cs/syo/index.htm.June, 2012. 
Молодша середня школа

\begin{tabular}{l|c|c|c}
\hline \multirow{2}{*}{\multicolumn{1}{c|}{ Предмет/години }} & \multicolumn{3}{c}{ Класи } \\
\cline { 2 - 4 } Читання & $\mathbf{7}$ & $\mathbf{8}$ & $\mathbf{9}$ \\
\hline Соціальні науки & 140 & 140 & 105 \\
\hline Математика & 105 & 105 & 140 \\
\hline Фізика/хімія (Науки) & 140 & 105 & 140 \\
\hline Музика & 105 & 140 & 140 \\
\hline Мистецтво & 45 & 35 & 35 \\
\hline Здоров'я, фізична культура & 45 & 35 & 35 \\
\hline Технічна, домашня економіка & 105 & 105 & 105 \\
\hline Іноземна мова & 70 & 70 & 35 \\
\hline Моральне виховання (курс ) & 140 & 140 & 140 \\
\hline Інтегроване навчання & 35 & 35 & 35 \\
\hline Спеціальна діяльність & 50 & 70 & 70 \\
\hline \multicolumn{1}{c|}{ Загальна кількість } & $\mathbf{3 5}$ & $\mathbf{3 5}$ & $\mathbf{3 5}$ \\
\hline
\end{tabular}

Як бачимо, виховний складник (а саме моральне виховання і спеціальна діяльність) у початковій школі (1 - 6 класи) становить 7,4 \% від загальної кількості годин, тоді як у молодшій середній (7 - 9 класи ) - 6,8\%. Моральне виховання як предмет викладається класоводом з 1 по 9 класи 1 годину на тиждень (35 годин на рік). У навчальній програмі старшої середньої школи (10 - 12 класи) цей предмет відсутній. Незважаючи на, здавалось би, невеликий відсоток, виховання в японській школі не обмежено кількістю офіційно відведених годин - натомість вбудовано в імпліцитну шкільну програму. Виховний акцент у старшій школі не зменшується. Важливою складовою змісту виховання старшокласників $є$ громадянське виховання (учні вивчають предмет “Сучасне суспільство”) (Isoda et al, 2007). особлива увага приділяється профорієнтаційній роботі; старшокласники продовжують бути задіяними у спеціальній діяльності.

Як і в більшості сучасних педагогічних систем, в Японії діє академічна свобода щодо розробки шкільної програми виховання із врахуванням положень Міністерства культури, науки і спорту Японії (MEXТ). Як додаток до курсу Міністерство освіти рекомендує використовувати на уроках серію підручників (наприклад, Torimatome (“Громадянські права”), Kokoro no Noto (“Щоденник серця”), зміст яких базується на чотирьох сферах, виокремлених у виховному ідеалі (1968р.):

1. Про себе.

2. Про стосунки з іншими.

3. Про стосунки людини з природою.

4. Про цінності колективу/групи та суспільства.

У процесі вивчення курсу морального виховання поширеним $є$ когнітивно-емоційний підхід: обговорення реальних життєвих ситуацій (ще Р. Бенедікт згадує про повчальну історію песика Хатіко - символу вірності й відданості в Японії, що розглядалася учнями 2 класу початкової школи (Benedict, 1946, p. 345); ілюстрація бажаних вчинків і дій (у 2016 р. ALT стажер в Японії, блогер - Джесіка Рох розповідає про один з уроків морального виховання, на якому вона була присутня. Учням демонструвалося відео про жінку, яка ціною свого життя врятувала жителів свого міста, повідомивши через гучномовець про цунамі, що насувалося у 2011 p. (Roh).

Один з ключових компонентів японської виховної системи є спеціальна діяльність учнів (tokkatsu), що, власне, робить японську систему виховання наскрізною і цікавою для її вивчення західними освітянами. 
Спеціальна діяльність (tokkatsu) (нижче подано таблицю місця спеціальних видів діяльності в японській початковій і середній школі) передбачає такі повсякденні заходи, як: прибирання (класу, туалету, спортивного залу), догляд за живою природою, шкільні обіди, учнівське самоврядування. Це і загальношкільні свята/події: фестиваль культури, дні спорту, свято талантів, виставка 3 каліграфії та ін., до підготовки яких учні докладають чимало зусиль і часу; плановані екскурсії до визначних історичних/культурних пам'яток, що у старшій школі мають подовжений на декілька днів формат. Сюди ж відносять і різноманітні секції: так звані клуби, зустрічі в яких регулярно тривають від двох до трьох годин. Умовно шкільні клуби поділяють на спортивні (плавання, атлетика, гімнастика, фітнес, бейсбол, футбол, баскетбол, кендо, дзюдо, пінг-понг, катання на лижах, сумо, гри в м'яч) і культурно-інтелектуального спрямування (духовий оркестр, японські шахи, хор, гумористичний гурток (rakugo), драма, традиційні мистецтва, науковий/історичний гурток та ін). Як правило, школи упроваджують секції на власний розсуд, враховуючи інфраструктуру/штат фахівців (lower secondary education in japan). Футбол i бейсбол в Японії - види спорту, в яких школярі змагаються на національному рівні. Найбільша аматорська спортивна подія Японії - це щорічний Національний літній турнір 3 бейсболу серед команд середніх шкіл.

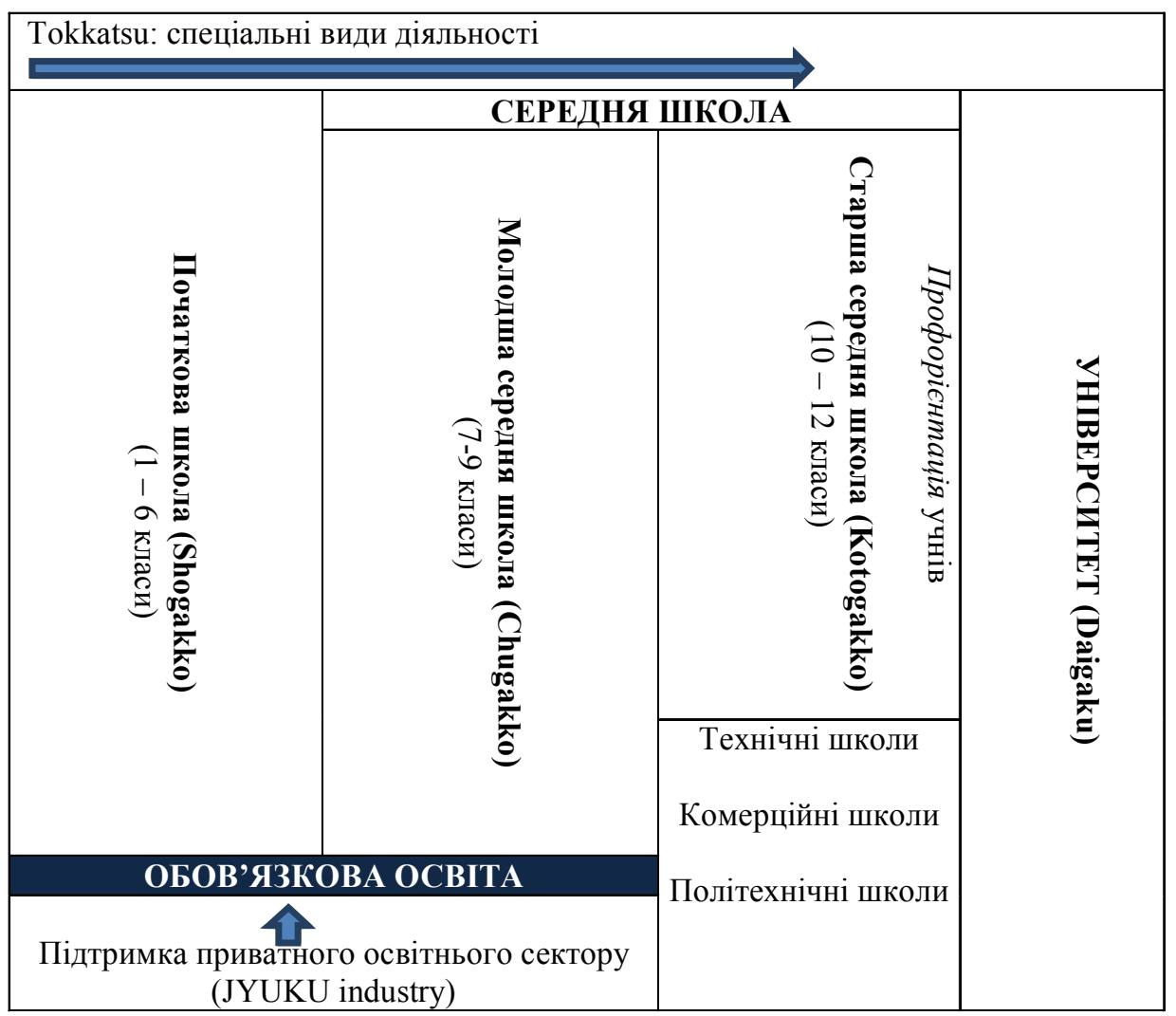

Як уважає К. Льюїс (Lewis), для західних педагогів спеціальна діяльність (tokkatsu) в японських школах $є$ не тільки моделлю успішної організації учнівського менеджменту, а й зразком розвитку в учнів приязного ставлення до школи. На думку послідовників теорії А. Маслоу - Е. Десі і Р. Райана, приязнь до школи розвивається у людини за умови створення відповідних соціально-контекстуальних умов, а також за умови задоволення школою трьох психологічних потреб учнів: 1) потреби у самоактуалізації (в автономності), що означає 
прагнення людини відчувати себе ініціатором власних дій, вчинків; 2) потреби у взаємодії, складники якої - дружба і підтримка - фундаментальні для емоційного здоров'я та соціального розвитку людини; 3) потреби у компетентності, що означає прагнення людини бути ефективною в діяльності, бажання досягти внутрішніх/зовнішніх результатів (Ryan \& Deci).

За К. Льюїс, японські школи задовольняють потребу дитини в автономії багатьма способами, зокрема, участю усіх без винятку учнів в управлінні класу/лідерстві (kyoshoku toban - група, що відповідає за обіди, shoji toban - відповідальні за прибирання). Потребу у взаємодії - через створення сприятливого виховного клімату - на доброзичливому ставленні і співпраці; підкреслюється важлива роль кожного. До слова, за спостереженням іншого японознавця П. Кейва, у шкільній практиці з 2007 року спостерігається зміна у назві шкільних груп від офіційного, холодного shudan (група) на nakama, що дослівно перекладається як “група підтримки”, навіть “друзі”, “товариші” з більш теплим відтінком ставлення до кола людей, до яких ти належиш (Cave, 2016, p. 82). Потребу своїх підопічних у компетентності японська школа задовольняє головним чином через різноманітні форми роботи, прищеплюючи інтерес до навчання (наприклад, в адаптаційний період учні молодшої школи можуть досліджувати усі кабінети, аби викликати інтерес до школи; або ж як завдання на літні канікули - зробити гру власними руками). Японські освітяни уважають, що посильні, творчі види роботи ( $1 / 3$ навчальної програми початкової школи - неакадемічні предмети (музика, мистецтво, фізична культура, спеціальні види діяльності) зменшують фрустрацію, посилюючи внутрішню мотивацію учнів. I чим сильніша мотивація, тим вірогідніше, що у подальшому буде сформована навчальна, а згодом і професійна компетентність. Тож наголос робиться не на конкуренції і розвиткові окремих навичок, а на участі, дії, докладанні зусиль (Lewis).

Ще один важливий момент системи виховання в Японії, який варто зазначити, - це взаємодія школи з іншими учасниками педагогічного процесу, а саме батьками і громадою.

В Японії школа є модератором батьків своїх учнів, їх ставлення до шкільних обов'язків і навчання дитини, у тому числі під час літніх канікул. Розпорядок дня, прогулянки, приготування сніданку - все те, що у західній культурі виконуються на літніх канікулах на розсуд батьків $\mathrm{i}$, здавалось би, не входить до компетентності освітнього закладу, перебуває під пильним шкільним контролем в Японії. Головну функцію батьків школа визначає так: “допомагати школі, спрямовувати енергію дитини у правильне русло з метою полегшення навчання і сприяння його продуктивності" ("Modern Japanese Culture”, 2007, с. 151). Більшість інформації про учнів учитель отримує безпосередньо у ході щоденного спілкування із ними, записів щоденника (де позначасться позашкільна діяльність учнів, раціон), анкет, коротких рефлексивних есе (в яких вивчається ставлення дитини до школи) (Fukuzawa, 1994, с. 72). Зібрані відомості $є$ цінними в контексті превентивної педагогіки: допомагають зрозуміти класоводу клімат в сім'ї, попередити ймовірну академічну неуспішність/дисциплінарні негаразди учня. Якщо школяр відзначає, що лягає спати об 11:30 чи 12:00, для класовода це сигнал про певну проблему в сім'ї (Fukuzawa, 1994, p. 15) i, відповідно, привід провести виховну роботу із батьками (усно, письмово, у вигляді директив).

Окрім батьківства, важливу роль у системі японського виховання/шкільництва виконує місцева громада, що визначає свою місію гаслом " $100 \%$ вчителі $+20 \%$ громада $=120 \%$ результат” (Bamkin, 2015). Прикладом тісної співпраці школи і громади $є$ вітальні дні (коли батьки, старшокласники, місцева громада вишиковуються вулицею, щоб привітати школярів із початком року, створюючи, таким чином піднесений настрій дітлахам і можливість відчути себе частиною громади); це і долучення дітей до суспільно корисної праці; поширеним стає 15-хвилинне читання книжок дітлахам перед уроками (не в усіх школах; залучаються усі охочі); це і спільні заходи за участю дітей і дорослих; уроки міжкультурного порозуміння, до яких залучають представників різних культур; це і так званий homework club (не плутати з jyuku) клуби, де школярам допомагають впоратись із домашнім завданням. 
Висновки. Підбиваючи підсумок стислого огляду сучасної системи виховання в Японії, вказуючи на усі їі переваги, ми, тим не менш, розуміємо, що, як і будь-яка інша педагогічна система, японська має також проблеми і слабкі сторони. Серед них: демографічна проблема, проблема ставлення до дітей іммігрантів, що часто зустрічають конфронтацію з боку традиційної суспільної; проблема збільшення кількості школярів, які відмовляються від навчання у школі; гендерна проблема на ринку працевлаштування молоді; потреба розвитку критичного мислення у старшокласників, викликана складнощами у написанні есе як частини вступних тестів (Harada, 2018, с. 111); нагальна проблема, висвітлена мас-медіа (“Record 37,000 children”) проблема збільшення випадків жорстокого поводження з дітьми. У сукупності обидві сторони, як позитивні, так і проблемні, складають реальну картину дійсності.

Враховуючи те, що сучасний світ має спільні інтереси, завдання і цілі, орієнтується на співпрацю і діалог, вважаємо за необхідне підходити до питання компаративної описової педагогіки із врахуванням усіх сторін, але "у контексті розвитку знань, миру, солідарності, кооперації, а не боротьби і протистояння" (Сорокин, 1992, с. 271). Подальшого аналізу потребуе реальна виховна практика, публікації, позбавлені ідеалізації і книжкових стереотипів; підручники 3 курсу морального виховання. Зібрана і проаналізована інформація дасть змогу не тільки зрозуміти специфіку японської виховної “інженерії”, розрізнити стійкі тенденції у вихованні на нормативному рівні, а й побачити плюси і мінуси української методики культурації і соціалізації дітей та юнацтва.

\section{ЛІТЕРАТУРА}

Гришелева, Л., Чегодарь Н. (1998). Японская культура нового времени. Эпоха Мэйдзи [Japanese culture in modern times. The Meiji era]. Москва: Восточная література.

Емота, И. (2018). Теория каваи [The Kawai theory]. Retrieved from https:// knigism. net

Ікеда, Д. (2013). Діалоги. Японія і Україна - різні долі, спільні надї [Dialogues. Japan and Ukraine - different fates, common hopes]. Київ: Генеза.

Молодякова, Э. (1996). Японское общество: книга перемен [Japanese Society: The Book of Changes]. Москва.

Молодякова, Э. (2014). Японское общество: изменяющееся и неизменное [Japanese society: changing and unchanging]. Москва: АИРО-ХХІ.

Сорокин, П. (1992). Человек, цивилизаиия, общество [Human, civilization, society]. Retrieved from https:// knigism. net

Херст, Дж. Идеаль бусидо: смерть, честь и преданность [Bushido ideals: death, honor and devotion]. Retrieved from https:// knigism. net

Bamkin, S. (2015). Moral education at Japanese elementary school. Retrieved from https://www. wcmt. org.uk/sites/default/files/report-documents/Bamkin\%20S\%20Report\%202015\%20 Final_0.pdf

Benedict, R. (1946). The Chrysanthemum and the Sword, Patterns of Japanese Culture. Boston: Houghton, Mifflin Company. [E-reader version]. Retrieved from https:// knigism. net

Cacizares-Esguerra, J., Maryks, R., Po-Chia Hsia, R. (2018). Encounters between Jesuits and Protestants in Asia and the Americas. Brill.

Cave, P. (2016). Schooling Selves: Autonomy, Interdependence, and Reform in Japanese Junior High Education. Chicago: University of Chicago Press.

Education in Japan: Past and Present. Retrieved from: http://www.nier.go.jp/ English/ educationjapan/ pdf/201103EJPP.pdf

Fukuzawa, R. (1994). The path to adulthood according to Japanese schools. Retrieved from http://www.jstor.org/stable/132784

Harada, T. (2018). The latest trend in the reform of high school education inJapan: Focusing on the curriculum reform. The Journal of Social Studies Education in Asia, Vol.7. 
Isoda, M., Stephens, M., Ohara, Y., \& Miyakawa, T. (Eds.). (2007). Japanese lesson study in mathematics: Its impact, diversity and potential for educational improvement. Singapore: World Scientific Publishing.

Japanese education. Retrieved from: http://members.tripod.com $/ \mathrm{h}$ javora/jed1.htm

Lewis, C. How Do Japanese Teachers Improve their Instruction? Synergies of Lesson Study at the School, District and National Levels. Retrieved from https://sites.nationalacademies.org/cs/groups/dbassesite/ documents/webpage/ dbasse_084385.pdf

Lewis, C. Implication of the Tokkatsu for Western Teachers. Retrieved from http://www.p.u-tokyo.ac.jp/ $\sim$ tsunelab /tokkatsu/edwc/

Maruyama H., (2013). Moral education in Japan. Retrieved from: https: //www.nier.go.jp /English/ educationjapan/ pdf/ 201303MED.pdf

Modern Japanese Culture and Society. (2007). New York: Routledge.

Naito, T. (1990). Modern education in Japanese public schools. Moral education forum. Vol.15

Okano, K., Oprandy, R., Tsuchiya, M. (1999). Education in Contemporary Japan: Inequality and Diversiy. Cambridge University Press.

Passin, H. (1965). Society and Education in Japan. Tokyo: Kфdansha.

Record 37,000 children suspected to have suffered abuse in Japan. Retrived from https://japantoday.com/ category/crime/ record-37-000-children-suspected-to-have-suffered-abuse-in-japan?.Oct.5, 2018

Reischauer, E. (1995). The Japanese today : change and continuity. Cambridge, Massachusetts; London : The Belknap Press of Harvard University Press.

Roesgaard, M. (2016). Moral Education in Japan: Values in a global context. London, New York: Routledge.

Roh, J. Moral education in Japan [Blog post] https://www.youtube.com/channel/UClAHZf Rt9yFbWfWbqMZEPGA

Ryan, R., Deci, E. Self-Determination Theory and the Facilitation of Intrinsic Motivation, Social Development, and Well-Being. Retrieved from https://selfdeterminationtheory.org/SDT/documents/ 2000_RyanDeci_SDT.pdf

The World of Tokkatsu. The Japanese approach to whole child education. Retrieved from http://www.p.u-tokyo.ac.jp/ tsunelab/tokkatsu/

Zhao, Y., Lei, J., Li, G., He, M., Okano, K., Megahed, N., Gamage, D., Ramanathan, H. (2010). Handbook of Asian Education: A Cultural Perspective. New York: Routledge.

\section{REFERENCES}

Grisheleva, L., Chegodar' N. (1998). Japonskaja kul'tura novogo vremeni. Jepoha Mjejdzi [Japanese culture in modern times. The Meiji era]. Moskva: Vostochnaja literatura.

Emota, I. (2018). Teorija kavai [The Kawai theory]. Retrieved from https:// knigism. net

Ikeda, D. (2013). Dialohy. Yaponiia i Ukraina - rizni doli, spil'ni nadii [Dialogues. Japan and Ukraine different fates,

Molodjakova, Je. (1996). Japonskoe obshhestvo: kniga peremen [Japanese Society: The Book of Changes]. Moskva.

Molodjakova, Je. (2014). Japonskoe obshhestvo: izmenjajushheesja i neizmennoe [Japanese society: changing and unchanging]. Moskva: AIRO-HXI.

Sorokin, P. (1992). Chelovek, civilizacija, obshhestvo [Human, civilization, society]. Retrieved from https:// knigism. net

Herst, Dzh. Idealy busido: smert', chest' i predannost' [Bushido ideals: death, honor and devotion]. Retrieved from https:// knigism. net

Bamkin, S. (2015). Moral education at Japanese elementary school. Retrieved from https:// www. wcmt. org.uk/sites/default/files/report-documents/Bamkin\%20S\%20Report\%202015\%20 Final_0.pdf 
Benedict, R. (1946). The Chrysanthemum and the Sword, Patterns of Japanese Culture. Boston: Houghton, Mifflin Company. [E-reader version]. Retrieved from https:// knigism. net

Cacizares-Esguerra, J., Maryks, R., Po-Chia Hsia, R. (2018). Encounters between Jesuits and Protestants in Asia and the Americas. Brill.

Cave, P. (2016). Schooling Selves: Autonomy, Interdependence, and Reform in Japanese Junior High Education. Chicago: University of Chicago Press.

Education in Japan: Past and Present. Retrieved from: http://www.nier.go.jp/English/educationjapan/ pdf/201103EJPP.pdf

Fukuzawa, R. (1994). The path to adulthood according to Japanese schools. Retrieved from http://www.jstor.org/stable/132784

Harada, T. (2018). The latest trend in the reform of high school education inJapan: Focusing on the curriculum reform. The Journal of Social Studies Education in Asia, Vol.7.

Isoda, M., Stephens, M., Ohara, Y., \& Miyakawa, T. (Eds.). (2007). Japanese lesson study in mathematics: Its impact, diversity and potential for educational improvement. Singapore: World Scientific Publishing.

Japanese education. Retrieved from: $\mathrm{http}: / /$ members.tripod.com/h_javora/jed1.htm

Lewis, C. How Do Japanese Teachers Improve their Instruction? Synergies of Lesson Study at the School, District and National Levels. Retrieved from https://sites.nationalacademies.org/cs/groups/ dbassesite/ documents/webpage/ dbasse_084385.pdf

Lewis, C. Implication of the Tokkatsu for Western Teachers. Retrieved from http://www.p.u-tokyo.ac.jp/ -tsunelab /tokkatsu/edwc/

Maruyama H., (2013). Moral education in Japan. Retrieved from: https: //www.nier.go.jp /English/ educationjapan/ pdf/ 201303MED.pdf

Modern Japanese Culture and Society. (2007). New York: Routledge.

Naito, T. (1990). Modern education in Japanese public schools. Moral education forum. Vol.15

Okano, K., Oprandy, R., Tsuchiya, M. (1999). Education in Contemporary Japan: Inequality and Diversiy. Cambridge University Press.

Passin, H. (1965). Society and Education in Japan. Tokyo: Kodansha.

Record 37,000 children suspected to have suffered abuse in Japan. Retrived from https://japantoday.com / category/crime/ record-37-000-children-suspected-to-have-suffered-abuse-in-japan?Oct.5, 2018

Reischauer, E. (1995). The Japanese today : change and continuity. Cambridge, Massachusetts; London : The Belknap Press of Harvard University Press.

Roesgaard, M. (2016). Moral Education in Japan: Values in a global context. London, New York: Routledge.

Roh, J. Moral education in Japan [Blog post] https://www.youtube.com/channel/UClAHZf Rt9yFbWfWbqMZEPGA

Ryan, R., Deci, E. Self-Determination Theory and the Facilitation of Intrinsic Motivation, Social Development, and Well-Being. Retrieved from https://selfdeterminationtheory.org/SDT/documents/ 2000_RyanDeci_SDT.pdf

The World of Tokkatsu. The Japanese approach to whole child education. Retrieved from http://www.p.u-tokyo.ac.jp/ tsunelab/tokkatsu/

Zhao, Y., Lei, J., Li, G., He, M., Okano, K., Megahed, N., Gamage, D., Ramanathan, H. (2010). Handbook of Asian Education: A Cultural Perspective. New York: Routledge. 